\title{
Kettős lumenứ mikrokatéterek alkalmazása krónikus teljes koronária-okklúzió katéteres revaszkularizációjában - Egy komplex beavatkozás tanulságai
}

\author{
Tajti Péter', Rami Abu Fanne², Ungi Imre', Katona András', Sasi Viktor', \\ Nagy Ferenc Tamás ${ }^{1}$
}

\author{
${ }^{1}$ Szegedi Tudományegyetem, Invazív Kardiológiai Részleg, II. sz. Belgyógyászati Klinika és Kardiológiai \\ Központ, Szeged \\ ${ }^{2}$ Hillel Yaffe Medical Center, Hadera, Izrael
}

Levelezési cím:

Dr. Tajti Péter

Szegedi Tudományegyetem, Invazív Kardiológiai Részleg, II. sz. Belgyógyászati Klinika és Kardiológiai Központ 6725 Szeged, Semmelweis u. 8.

E-mail: ptajti@gmail.com

\begin{abstract}
A krónikus, teljes koszorúér-okklúzió (CTO) perkután intervenció (PCI) sikeres és biztonságos kivitelezhetősége jelentősen javult az arra felkészült centrumokban az elmúlt években. Ugyanakkor az anamnézisben szereplő aorto-koronáriás bypass graft (ACBG) mütét jelentős mértékben csökkenti a CTO $P C I$ sikerességét miközben emeli a beavatkozáshoz társuló szövődmények gyakoriságát. A komplex koronária anatómiájából adódó nehézségek megoldása gyakran elörehaladott technikák ismeretét és eszközök alkalmazását követeli meg az effektív és biztonságos intervenciók kivitelezéséhez ezen speciális betegpopulációban. Jelen esetbemutatásunkban egy korábban két alkalommal sikertelen anterográd CTO-rekanalizáción átesett poszt-ACBG-beteg komplex retrográd intervencióját ismertetjük. A beavatkozás során a komplex jobb koronária-bifurkáció és a korábban erre varrott, majd elzáródott saphena véna graft helyzete miatt egyedülálló módon retrográd és anterográd kettős lumenủ mikrokatéterrel facilitált rekanalizációs technikát alkalmaztunk, amely eredményeképpen sikeres CTO-megnyitást végeztünk.
\end{abstract}

Kulcsszavak: kettős lumenủ mikrokatéter, aorto-koronáriás bypass graft mütét, krónikus teljes okklúzió, perkután koronária-intervenció

Application of dual lumen microcatheters in chronic total occlusion percutaneous coronary interventions lessons learned from a complex case

The success rate and safety of percutaneous coronary intervention (PCl) of chronic total coronary occlusions (CTO) in dedicated CTO centers has significantly improved recently. History of prior coronary artery bypass graft surgery (CABG) in patients undergoing $\mathrm{CTO} \mathrm{PCl}$ is associated with lower procedural success and higher rates of major procedural complications. Increased complexity of coronary anatomy requires the use of advanced interventional techniques and devices in order to achieve successful CTO revascularization safely and effectively in such a challenging patient population. In our current case we present a complex right coronary CTO recanalization in a patient with a history of CABG surgery who had undergone two previous failed antegrade CTO attempts in an outside hospital. Given the complexity of the distal right coronary artery bifurcation and pre-branch saphenous vein graft (SVG) anastomosis we used the dual lumen microcatheter in a unique way both retrogradely and antegradely to preserve side-branches and achieve success.

Keywords: dual lumen microcatheter, coronary artery bypass graft operation, chronic total occlusion, percutaneous coronary intervention 


\section{Bevezetés}

Korszerü eszközök, újabb technikák és algoritmusok megjelenése a krónikus teljes koronária-okklúziók (CTO) perkután koronária-intervenciójában $(\mathrm{PCI})$ a sikerráta jelentős növekedését eredményezte (85$90 \%$ ) tapasztalt operatörök kezében (1-3). Ugyanakkor a korábban aorto-koronáriás bypass graft ( $A C B G)$ műtéten áteset betegek esetében továbbra is nagy technikai kihívást jelent a krónikus okklúziók revaszkularizációja. Ennek hátterében elsősorban többszörös társbetegségek jelenléte, illetve anatómiai sajátságok állnak (anasztomózis lokalizációja, disztális bifurkáció potenciális jelenléte, meszesedés foka, a perikardiális hegesedés miatti epikardiális koronáriák merevsége, koronária-tortuozitás, „tenting" jelenség [zsugorodott SVG által felhúzott érlefutás mindig a graftba vezeti mind az antero-, mind a retrográd eszközöket és néha lehetetlenné teszi az éles kanyar bevételét a „sátor” tetején]) $(4,5)$. Jelen esetünkön keresztül ismertetjük a kettős lumenü mikrokatéter (a rapid exchange [RX] disztális port és proximális over-the-wire [OTW] oldalsó port struktúra szimultán 2 vezetődrót bevezetését teszi lehetővé) hasznosságát anterográd és retrográd drótozás esetében, amely komplex anatómiai helyzetekben nyújthat effektív megoldást speciális CTO-intervenciókban (poszt-ACBG, bifurkáció).

\section{Esetismertetés}

A 75 éves férfi beteg kórelőzményében hipertenzió, dyslipidaemia, inzulinnal kezelt 2-es típusú diabetes mellitus szerepelt. Revaszkularizációs anamnézisből kiemelendő 1999 RCA (right coronary artery) PCl (bare metal stent, BMS), 2000-ben RCA stentokklúzió és reziduális szükületek miatti ACBG-mütét (LIMA-LAD, SVG-CXOM, SVG-RCA, SVG-I. diagonális ág), valamint 2016-ban az RCA véna graft okklúziója miatti graft $\mathrm{PCl}$ (drug eluting stent, DES). Rekurráló panaszok miatt 2018-ban elvégzett koronarográfia során okkludált véna graftok igazolódtak (SVG-RCA, SVG-diagonális ág, SVG-CXOM), amely miatt első lépésben $\mathrm{CX} P C I$ történt (DES). Kardiális mágneses rezonancia (cMR) által igazolt hátsófali viabilitás igazolása után és optimális gyógyszeres terápia beállítása ellenére perzisztáló panaszok (CCS 2-3 angina ekvivalens fulladás) miatt hazánk egy másik centrumában két alkalommal is sikertelen anterográd RCA-rekanalizációs kísérletet végeztek. Ezt követően vettük fel a betegünket ismételt jobb koronária-revaszkularizációs kísérlet elvégzése céliából.

Bal arteria radialis és jobb arteria femoralis punkcióját követöen 7 French EBU 4.0 valamint 7 French $A L$ 1.0 katéterekkel kanüláltuk a bal közös törzset, illetve a jobb koronária-szájadékot. Bilaterális injekció alapján (1. ábra $A$ panel) aneurizmatikusan tágult proximális

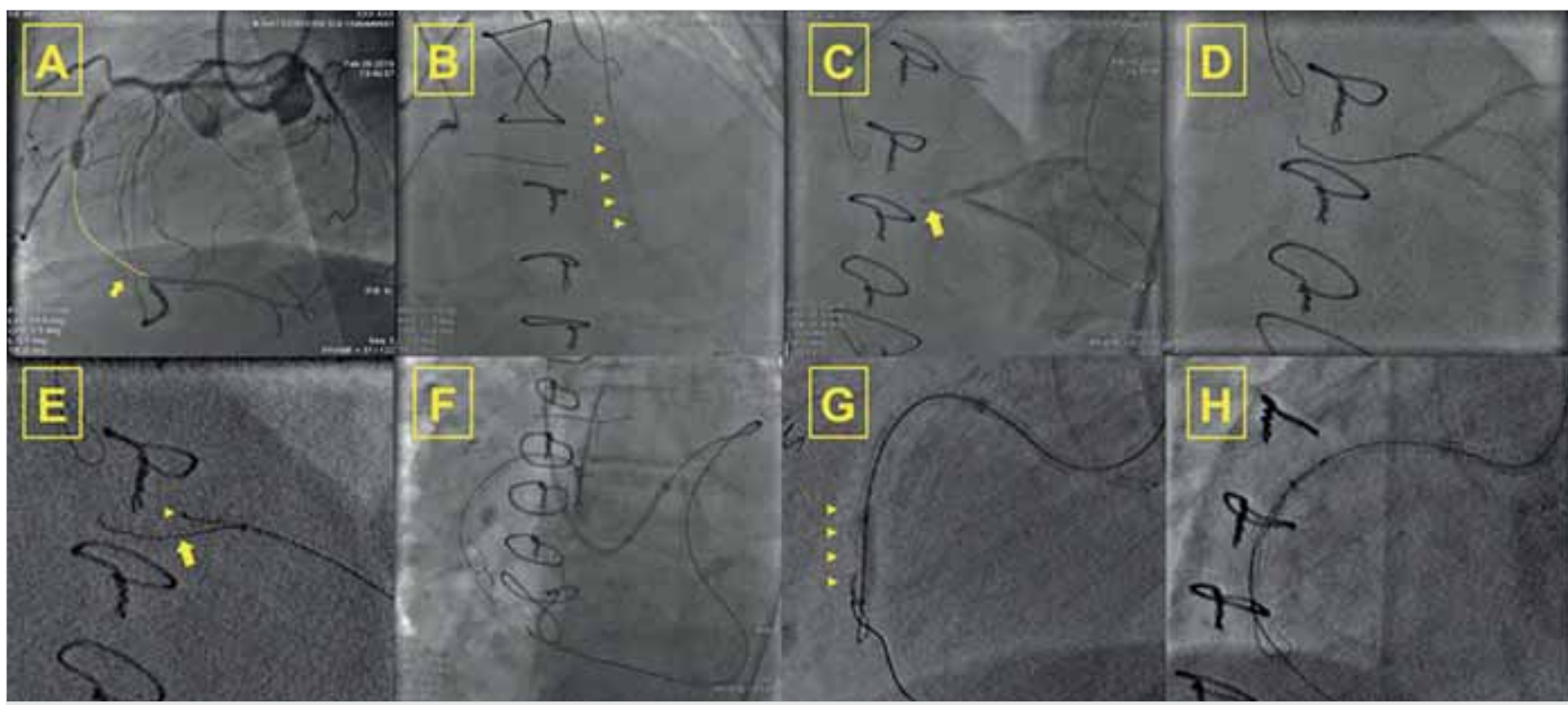

1. ÁBRA. Kettős lumenű mikrokatéter retrográd alkalmazása krónikus teljes koronária-okklúzió (CTO) perkután intervenciója (PCl) során. A: Bilaterális injekció reprezentálja a crux-ig terjedő disztális jobb koronária krónikus okklúziójának disztális és proximális anatómiáját. B: Retrográd mikrokatéter (Corsair Pro [Asahi Intecc. Nagoya, Japan]) tip injekciója. C: Sikeres disztális CTO-sapkához történő drótozás (Sion [Asahi Intecc. Nagoya, Japan], Corsiar Pro). D: Saphena graftba parkolt Confianza Pro 12 vezetődrót [Asahi Intecc. Nagoya, Japán]. E: Retrográd kettős lumenű mikrokatéter (Sasuke [Asahi Intecc. Nagoya, Japán]) alkalmazása a disztális sapka over-the-wire (OTW) porton keresztül történő punkciójához. F: Anterográd es retrográd „knuckle" drótok (Fielder XT, Pilot 200 [Asahi Intecc. Nagoya, Japan]) koaxiális pozícióban. G: Sikertelen reverz CART (controlled antegrade and retrograde subintimal tracking) retrográd disszekció és re-entry technika a vertikális jobb koronáriaszakaszon. H: GuideLiner (Vascular Solutions, Minneapolis, MN, USA) reverz CART technika vezérelte vezetődrót belepés az anterográd vezetőkatéterbe 
RCA, tompa okklúziós sapka, valamint kielégítő disztális retrográd telődés (Rentrop 2-3, dominánsan szeptális kollaterálisokon keresztül) volt detektálható. Kezdő stratégiaként anterográd drót eszkalációt kíséreltünk meg Gaia 2 és Fielder XT (mindkettő Asahi Intecc, Nagoya, Japán) vezetődrótok és Corsair Pro (Asahi Intecc, Nagoya, Japán) mikrokatéter szupportjával. Rövid próbálkozások után azonban szubintimális drótpozíció volt sejthető, így „knuckle” drót segítségével tompa preparálással jutottunk a disztális jobb koronáriaszakaszba, majd egy rendkívül kemény, áthatolhatatlan szegmentum miatt retrográd technikára tértünk át. Kontrasztanyag-vezérelt drótozás révén (mikrokatéter tip injekciók) (1. ábra $B$ panel) sikeresen passzáltuk a szeptális kollaterális csatornát (Sion [Asahi Intecc, Nagoya, Japán] Corsair Pro). Többszöri próbálkozás ellenére sem sikerült azonban a disztális sapkát áttörni (1. ábra $C$ panel) (Fielder XT, Gaia 3, Sion), mivel a már említett „tenting” jelenség miatt ismételten a disztális jobb koronária-bifurkáció előtt anasztomizált okkludált véna graftba jutottunk (Confianza Pro 12 [Asahi Intecc, Nagoya, Japán]). A komplex anatómia megoldásaként a véna graftba parkolt vezetődrótot (1. ábra $D$ panel) felhasználva Sasuke kettős lumenú mikrokatétert juttattunk (Asahi Intecc,
Nagoya, Japán) abba, majd annak oldal-portján (OTW port) keresztül megfelelő szupportot és irányt tudtunk biztosítani a második retrográd drót sikeres disztális sapka punkciójához (1. ábra E panel) (Miracle 6 [Asahi Intecc, Nagoya, Japán]). Következő lépésben a Sasuke mikrokatétert Corsair Pro-ra cserelve retrográd Pilot 200 (Asahi Intecc, Nagoya, Japán) „knuckle” drót segítségével megfelelő koaxiális drótpozíciót vettünk fel az anterográd drót magasságában (1. ábra $F$ panel). GuideLinerrel (Vascular Solutions, Minneapolis, MN, USA) asszisztált reverz CART (controlled antegrade and retrograde subintimal tracking) technikával sikeresen az anterográd vezető katéterbe jutottunk (1. ábra $G$ és $H$ panel). Ezt drót externalizáció követte, azaz $330 \mathrm{~cm}$-es RG3 (Asahii Intecc., Nagoya, Japán) drótot juttatunk a retrográd vezető katéter felöl a mikrokatéter lumenen át az anterográd vezető katéterbe, majd ezt anterográd vezetődrótként használva ballon predilatációt végeztünk az okkludált szegmentumban. Kontralaterális angiogramok és szimultán disztális RCA-ballon infláció útján győződtünk meg arról, hogy a cruxban retrográd disszekció alakult ki. Ezzel a vizualizációs technikával elkerülhettük az anterográd disszekciós tasak hidraulikus expanzióját. Tekintettel a disszekcióra és az oldalág megőrzés

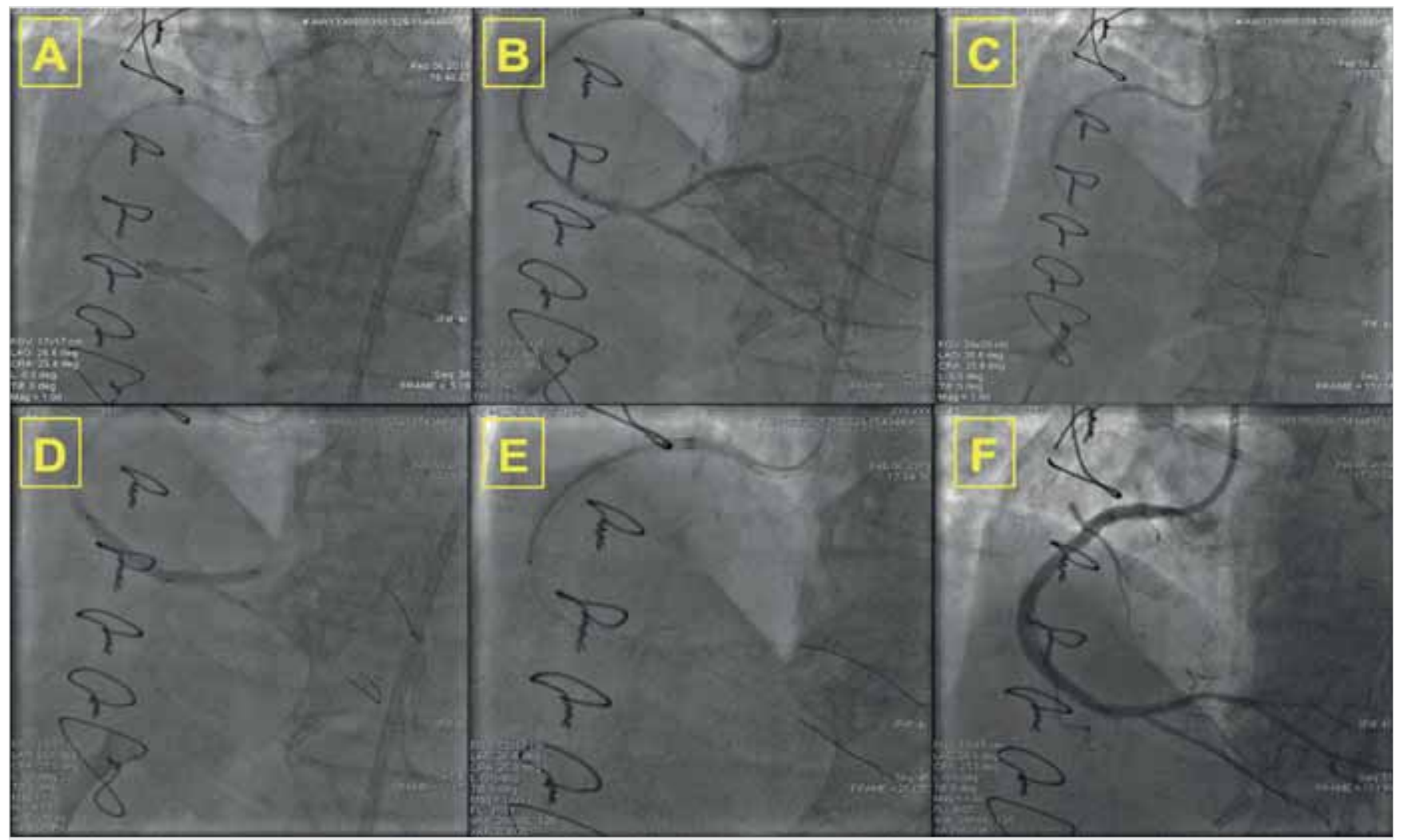

2. ÁBRA. Kettős lumenű mikrokatéter anterográd alkalmazása krónikus teljes koronária-okklúzió (CTO) perkután intervenciója (PCI) során. A: Kissing-ballon tágítás a poszterolaterális oldalág kettős lumenű Sasuke (Asahi Intecc. Nagoya, Japan) való újradrótozást követően. B: GuideLiner (Vascular Solutions, Minneapolis, MN, USA) facilitált angiográfia, amely perzisztáló crux disszekciót mutat. C: Sasuke asszisztált poszterior descendens ág drótozás majd externalizált dróteltávolítás. D: "Crossover" stentelés a poszterolaterális ág fele. E: Proximális stent-implantáció reziduális proximális disszekció miatt. F: Sikeres jobb koronária CTO-intervenció 3 gyógyszerkibocsájtó stent implantációjával 
fontosságára, a poszterolaterális $(\mathrm{PL})$ ág drótozásához ismételten a Sasuke kettős lumenü mikrokatétert használtuk, majd kissing dilatációkat végeztünk a crux bifurkációjában (2. ábra $A$ panel). A perzisztáló jobb koronária crux disszekció miatt (2. ábra $B$ panel) ismételten a kettős lumenú mikrokatétert alkalmaztuk - ezúttal az anterográd PL-drótra vezetve - és az OTW-lumenen át újra drótozást végeztünk a poszterior descendens (PD) ágba (2. ábra $C$ panel). Ezt követően a retrográd externalizációs drótot már biztonsággal eltávolíthattuk, hiszen mindkét ágban biztosan intraluminális anterográd drót állt rendelkezésünkre. A PL-ág felé „crossover” stentelést végeztünk (2. ábra $D$ panel), majd a Sasuke mikrokatéter segítségével a stent cellákon át a PD-ágat ismételten drótoztuk. Utolsó lépésben kissing utótágítást végeztünk és két addicionális gyógyszerkibocsátó stentet helyeztünk be (2. ábra $E$ panel), jó angiográfiás végeredménnyel (2. ábra $F$ panel) (kontrasztanyag 320 $\mathrm{ml}$, procedurális idő 257 min, sugár dózis 2,114 Gray). A beteget, 48 órás eseménytelen obszervációját követően, stabil és panaszmentes állapotban otthonába bocsájtottuk.

\section{Megbeszélés}

Irodalmi ismereteink szerint esetünk egyedülállóan mutatja be retrográd kettős lumenű mikrokatéter többszörös alkalmazását korábban ACBG-mütéten átesett beteg CTO rekanalizációja céljából (3. ábra). Ennek során 1. az eszközt retrográd úton szeptális kollaterálison át a disztális föágba hatolásra;
2. anterográd irányban a disszekált PL-ág lumenének elérésére;

3. anterográd irányban a PD-ág lumenének elérésére;

4. crossover stenten át a PD-ág újradrótozására használtuk.

Esetünk azt példázza, hogy komplex technikák alkalmazása fontos sarokpontja a krónikus okklúziók megnyitásában az oldalágvesztés elkerülésének, mely meghatározó lehet a hosszú távú poszt-PCl-mortalitás csökkentésében.

Számos tanulmány vizsgálta az ACBG-mütött betegekben végzett CTO-rekanalizációk eredményeit rövid és hosszú távon. Christopoulos és munkatársai 496 betegben vizsgálták a hibrid algoritmus alkalmazását CTO PCl-ben post-ACBG-betegekben ( $n=176,35 \%)$, ACBG nélküli csoporttal összehasonlítva $(n=320)(4)$. Az ACBG-betegekben gyakrabban volt szükség retrográd technikák alkalmazására (39\% vs. 24\%, p<0,001), valamint az intervenciós sikerarány (88\% vs. 93\%, $p=0,04)$ csökkenő tendenciát mutatott, megfelelöen reprezentálva ezen klinikai esetek komplexitását. Ugyanakkor a beavatkozást követően nem mutatkozott számottevő különbség a szövődményeket illetően (major adverse cardiac event, MACE; 2,1\% vs. 1,1\%, $\mathrm{p}=0,40)$. Azzalini és munkatársai hasonló tendenciájú klinikai sikerarányt találtak 2058 esetszámú (ACBG [ $n=401] 82 \%$ vs. non-ACBG [ $n=1657] 88 \%, p=0,001)$ heterogén betegpopulációban (multicentrikus vizsgálat) (5). Ezen tanulmány alapján - a korábbiakkal ellentétben - szignifikánsan magasabb periprocedurális komplikáció ráta (MACE, $3,7 \%$ vs. $1,5 \%, p=0,0004$ ), és medián 377 napos utánkövetési idővel magasabb kar-

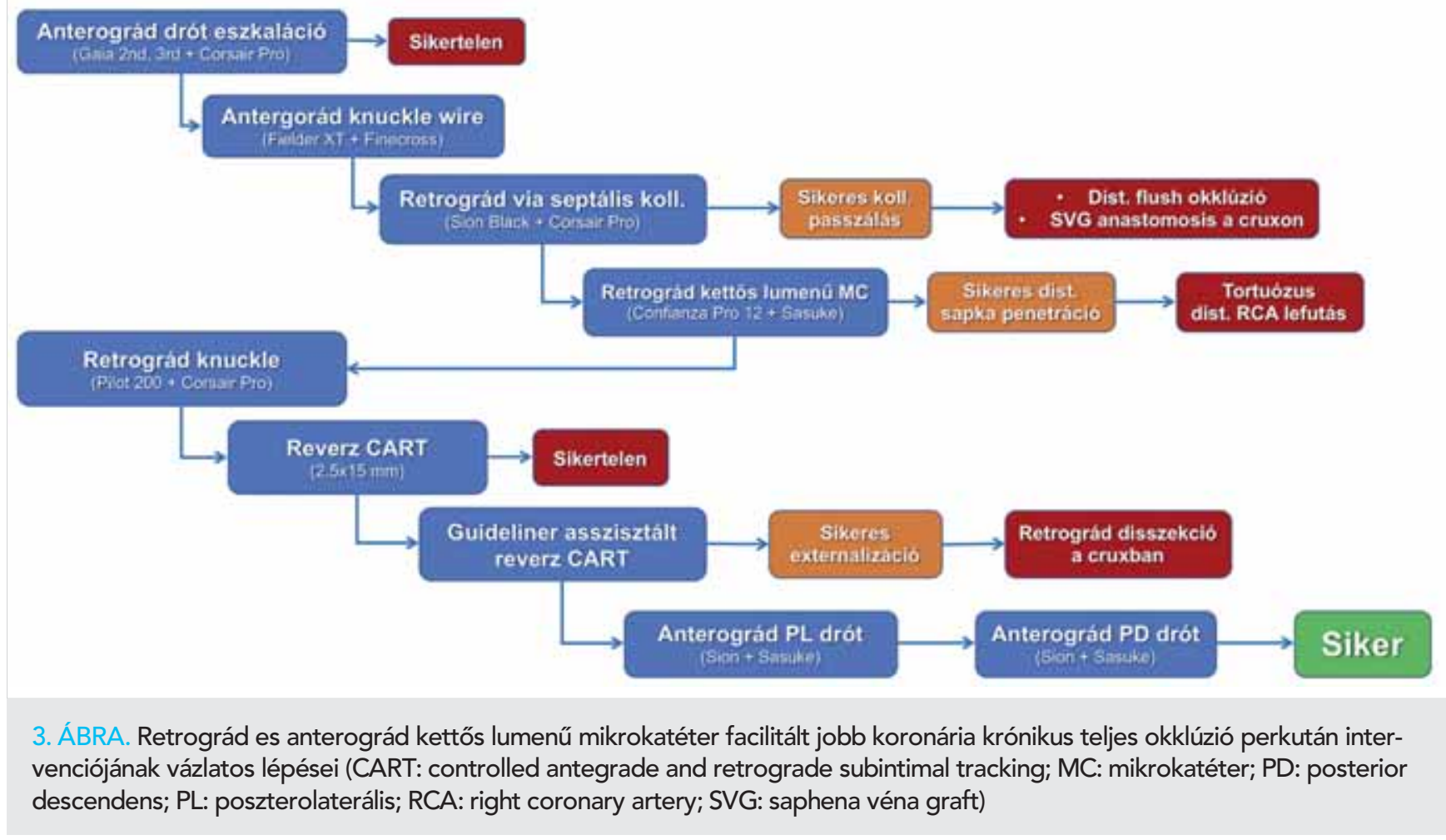




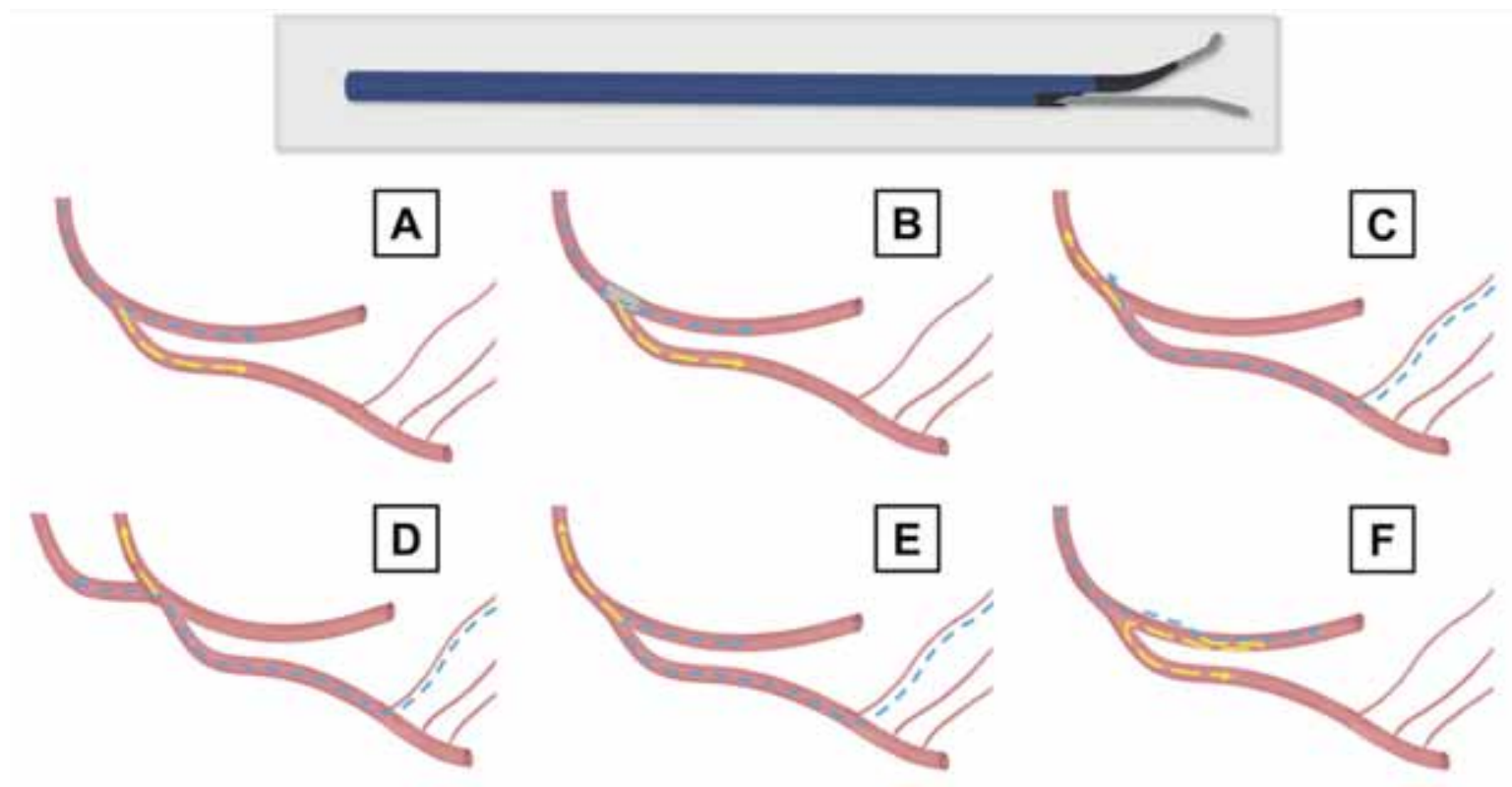

4. ÁBRA. A kettős lumenű mikrokatéter felhasználási lehetőségei bifurkáció drótozás esetén („over-the-wire” port [OTW, sárga], „rapid-exchange” port [RX, kék]). A: Anterográd bifurkáció-drótozás. B: Anterográd bifurkáció (újra) drótozás „stent strutok"-on keresztül. C: Retrográd parallel drótozás szubintimálisan parkolt első retrográd dróton (RX) felvezetett kettős lumenű mikrokatéter "over the wire" (OTW) portját felhasználva. D: Retrográd kettős lumenű mikrokatéter felhasználása SVG-graftban parkolt RX-drót, és OTW-oldalport drót segítségével. E: Retrográd poszterior descendens $(\mathrm{PD})$ poszterolaterális $(\mathrm{PL})$ drótozás RX-porton, majd OTW-porton keresztüli disztális sapkapunkció. F: Disztális re-entry-t követően a valódi lumenben parkolt RXdrót, és reverz OTW-drót segítségével történő bifurkációs oldalágdrótozás anterográd úton

diális mortalitás $(3,8 \%$ vs. $1,9 \%, p=0,02)$, „target” lézió re-intervenció $(11,5 \%$ vs. $6,6 \%, p<0,001)$, és „target” lézió területi miokardiális infarktusban $(2,0 \%$ vs. $0,7 \%$, $\mathrm{p}=0,04)$ mutatkozott az ACBG-csoportban. Mindemellett az ACBG-mütöttek CTO-intervenciójához felhasznált kontrasztanyag-mennyiség, sugárdózis és procedurális idő is szignifikánsan meghaladja a non-ACBG CTO-intervenciókét $(3,4)$. Ezen legfrissebb tanulmányok alátámasztják, hogy előzetes ACBG-mútét után elzáródott SVG-ok mellett a CTO perkután intervenciója rendkívül komplex beavatkozás. Európai statisztikai adatok alapján ritkábban találkozunk ACBG utáni CTOval $(15-22 \%)(1,2,6)$, mint az Egyesült Államokban $(28-37 \%)(3,4)$.

A jelentős oldalágak megőrzése valamint a periprocedurális infarktus elkerülése CTO PCI során kritikus fontosságú a betegek hosszú távú mortalitásának csökkentésében $(7,8)$. Az okklúzió szegmentumában eredő nagy oldalág (okklúziótól proximálisan, az okklúzió magasságában, valamint okklúziótól disztálisan) elfordulási incidenciája 26,5-33,0\% közöttire tehető a perkután intervenciós kísérleten áteső betegek körében (9). Tekintettel arra, hogy minden 3. esetben a bifurkáció is érintett speciális „oldalág-mentési” technikákra lehet szükség. A proximális oldalág elsősorban horgonyzási technikák alkalmazásában lehet releváns, valamint preventív drótozás válhat szükségessé az anterográd drót eszkaláció megkezdése előtt, ugyanakkor oldalágvesztés lehetőségével ritkán, csak retrográd, súlyosan propagálódó disszekció esetén érdemes számolnunk. Ezzel szemben az okklúzió testében, valamint az elzáródás disztális sapkájánál eredő oldalág megőrzése jelentős mertekben csökkenti a beavatkozás klinikai sikerarányát (3).

Bemutatott esetünk jól szemlélteti az ACBG és bifurkációk együttese által okozott technikai akadályokat CTO $\mathrm{PCl}$ során, amelyek azonban a megfelelő eszközök használatával áthidalhatók. A retrográd mikrokatéterek használata jelentős mértékben függ a kollaterális méretétől és annak tortuozitásától (szeptális, epikardiális, vagy saphena véna graft), ezért a megfelelő mikrokatéter választásában a tip profiljának és átmerőjének fontos szerepe van. Habár több kettős lumenű mikrokatéter érhető el világszerte (Twin-Pass, Twin-Pass Torque [mindkettő Teleflex, Wayne, PA, USA], Crusade [Kaneka, Tokió, Japán], Fine Duo [Terumo, Tokió, Japán], NHancer [IMDS, Roden, Hollandia]), az általunk hazánkban elsőként alkalmazott Sasuke az egyedüli biztosságosan alkalmazható alacsony tip-profilú katéter, amely a szeptális kollaterálisok többségén is biztonságosan átvezethető (tip átmerő 1,5 Fr vs. 1,8 Fr [Fine Duo] vs. 2,0 Fr [Twin-Pass] vs. 2,1 Fr [Twin-Pass Torque] vs. 2,2 Fr [Crusade], 2,3 [NHancer]). Epikardiális kollaterálisokon keresztüli applikációja jelenleg nem került leírásra, és ennek magasabb perforáció rizikó miatt a használatát jelenleg nem javasoljuk. Ezen speciális esetünkben egyedülállóan „kihorgonyoztuk” a retrográd mikrokatétert az okkludált SVG disztális sza- 
kaszán, amely kellő szupportot adott a kemény disztális sapka második dróttal történő penetrációjához (4. ábra $D$ panel). Mindemellett a retrográd kettős lumenủ mikrokatéter alkalmazható sikeres PL-PD, vagy PD-PL-ág drótozásakor (véna graft involválása nélkül) a disztális sapka punkciójához (4. ábra $E$ panel). A kettős lumenü mikrokatéter alkalmazása retrográd parallel drótozásra is használható, mely szubintimális retrográd drótpozíció mellett az OTW-port használatával a második vezetődrót révén az intraluminális pozíció visszanyerhető (10) (4. ábra C panel). Ugyanakkor kiemelendő, hogy a kettős lumenű mikrokatéterek alkalmazása elsősorban disztális tip profiljuk miatt dominánsan anterográd drótozáshoz használatosak (4. ábra $A$ panel). Főbb alkalmazási indikációs köréhez tartozik továbbá a szubintimális drótpozíciót követően egy második vezetődróttal történő „reentry” a disztális valódi lumenbe, valamint okklúziós test, illetve disztális sapkabifurkáció esetén anterográd drótozáshoz (4. ábra $F$ panel). Két stentes bifurkációs technika alkalmazásakor a kettős lumenú mikrokatéter szinten kiválóan alkalmas a stent cellákon keresztüli vagy éles szögben eredő oldalágba bejutás megkönnyítésére (4. ábra $B$ panel).

\section{Következtetések}

A kettős lumenű mikrokatéterek hasznos eszközként szolgálhatnak a bifurkációt érintő és/vagy elzáródott graft által megnehezített natív krónikus teljes koronária-okklúzió intervenciókban, megkönnyítve az anterográd és retrográd drótozást az oldalág megőrzését.

\section{Irodalom}

1. Wilson WM, Walsh SJ, Yan AT, et al. Hybrid approach improves success of chronic total occlusion angioplasty. Heart 2016; 102:
1486-93. DOI:10.1136/heartjnl-2015-308891

2. Maeremans J, Walsh S, Knaapen P, et al. The Hybrid Algorithm for Treating Chronic Total Occlusions in Europe: The RECHARGE Registry. J Am Coll Cardiol 2016; 68: 1958-1970. DOI: 10.1016/j. jacc.2016.08.034

3. Tajti P, Karmpaliotis D, Alaswad K, et al. The Hybrid Approach to Chronic Total Occlusion Percutaneous Coronary Intervention: Update From the PROGRESS CTO Registry. JACC Cardiovasc Interv 2018. DOI:10.1016/j.jcin.2018.02.036

4. Christopoulos G, Menon RV, Karmpaliotis D, et al. Application of the "hybrid approach" to chronic total occlusions in patients with previous coronary artery bypass graft surgery (from a Contemporary Multicenter US registry). Am J Cardiol 2014; 113: 1990-4. DOI:10.1016/j.amjcard.2014.03.039

5. Azzalini L, Ojeda S, Karatasakis A, et al. Long-Term Outcomes of Percutaneous Coronary Intervention for Chronic Total Occlusion in Patients Who Have Undergone Coronary Artery Bypass Grafting vs Those Who Have Not. Can J Cardiol 2018; 34: 310-318. DOI:10.1016/j.cjca.2017.12.016

6. Galassi AR, Sianos G, Werner GS, et al. Retrograde Recanalization of Chronic Total Occlusions in Europe: Procedural, In-Hospital, and Long-Term Outcomes From the Multicenter ERCTO Registry. J Am Coll Cardiol 2015; 65: 2388-400. DOI: 10.1016/j. jacc.2015.03.566

7. Jang WJ, Yang JH, Choi SH, et al. Association of periprocedural myocardial infarction with long-term survival in patients treated with coronary revascularization therapy of chronic total occlusion. Catheter Cardiovasc Interv 2016; 87: 1042-9. DOI:10.1002/ccd.26286

8. Galassi AR, Boukhris M, Tomasello SD, et al. Incidence, treatment, and in-hospital outcome of bifurcation lesions in patients undergoing percutaneous coronary interventions for chronic total occlusions. Coron Artery Dis 2015; 26: 142-9. DOI: 10.1097/ MCA. 0000000000000194

9. Ojeda S, Pan M, Gutierrez A, et al. Bifurcation lesions involved in the recanalization process of coronary chronic total occlusions: Incidence, treatment and clinical implications. Int J Cardiol 2017; 230: 432-438. DOI: 10.1016/j.ijcard.2016.12.088

10. Tanabe G, Oikawa Y, Yajima J, Matsuno S, Kano H, Yamashita T. Retrograde parallel wire technique using a dual lumen catheter can be useful for percutaneous coronary intervention with chronic total occlusion. J Cardiol Cases 2018; 17: 25-28. DOI: 10.1016/j. jccase.2017.08.014 